\title{
PCPP-260, A Purkinje Cell-Specific Cyclic AMP-Regulated Membrane Phosphoprotein of $M_{r} \mathbf{2 6 0 , 0 0 0}$
}

\author{
S. Ivar Walaas, Angus C. Nairn, and Paul Greengard \\ Laboratory of Molecular and Cellular Neuroscience, The Rockefeller University, New York, New York 10021
}

The present study reports the existence of Purkinje cell-specific phosphoprotein, $M_{r}$ 260,000 (PCPP-260), a neuronal membrane phosphoprotein, in cerebellar Purkinje cells. PCPP-260, which on sodium dodecyl sulfate-polyacrylamide gel electrophoresis has an apparent molecular mass of $260,000 \mathrm{Da}$, has been found to be phosphorylated in particulate preparations by endogenous or added exogenous cyclic AMP-dependent protein kinase, but not by cyclic GMP-dependent, calcium/calmodulin-dependent or calcium/phospholipid-dependent protein kinases. The protein has been found in high concentrations in all mammalian cerebella so far analyzed, including human cerebellum. Oneand two-dimensional electrophoretic and peptide mapping analyses of proteins in other brain regions show that a closely related 265,000 Da phosphoprotein also exists, albeit in low concentrations, outside the cerebellum. Analysis of cerebella from mutant mice, deficient in either Purkinje cells or in granule cells, indicates that PCPP-260 within the cerebellum is restricted to Purkinje cells. Furthermore, subcellular fractionation of rat cerebella indicates that the protein is an integral membrane protein. The cAMP-regulated phosphorylation of PCPP-260 is presumably involved in membrane functions important to Purkinje cells.

The second messengers cyclic AMP (cAMP) and cyclic GMP (cGMP) achieve most or all of their effects through activation of specific protein kinases (Greengard, 1978, 1981). Both second messengers appear to be important in the function of neurons in the mammalian cerebellum (e.g, Bloom, 1975; Ferrendelli, 1978; Nairn and Greengard, 1983). However, only a limited number of cerebellar phosphoprotein substrates for cAMP-dependent or cGMP-dependent protein kinase have been characterized (Dolphin and Greengard, 1981; Dolphin et al., 1983; Schlichter et al., 1978, 1980). We recently reported the occurrence of a brain phosphoprotein of apparent molecular mass $260 \mathrm{kDa}$ in rat cerebellum (Walaas et al., 1983a). In the present work we have characterized both the protein kinase responsible for its phosphorylation, demonstrated that the protein is present in primate, rodent, and bovine cerebellum, and studied the cellular and subcellular localization of this protein in the rodent cerebellum. The protein appears to be specifically concentrated in the Purkinje cells, and has therefore been designated PCPP260 (Purkinje cell-specific phosphoprotein, $M_{r}$ 260,000).

Received May 16, 1985; revised Aug. 14, 1985; accepted Aug. 23, 1985.

This work was supported by the United States Environmental Protection Agency under Assistance Agreement CR-810608-01. We thank Dr. Tamas Bartfai for providing us with human and monkey brain samples.

Correspondence should be addressed to S. Ivar Walaas, M.D., Laboratory of Molecular and Cellular Neuroscience, The Rockefeller University, 1230 York Avenue, New York, NY 10021.

Copyright (C) 1986 Society for Neuroscience $0270-6474 / 86 / 040954-08 \$ 02.00 / 0$

\section{Materials and Methods}

\section{Materials}

$\gamma_{-32}{ }^{32}$-ATP was synthesized by the method of Glynn and Chappell (1964). Staphylococcus aureus V8 protease was from Miles Biochemicals; trypsin from Worthington; Trasylol from Mobay Chemical Corp.; pepstatin A, 8-bromo-cAMP, and 8-bromo-cGMP from Sigma. Phosphatidyl-

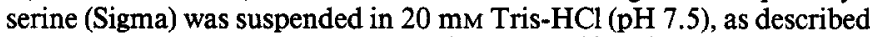
by Walaas et al. (1983a). Calmodulin was purified from bovine brain by the method of Grand et al. (1979). The catalytic subunit of cAMPdependent protein kinase was purified from bovine heart as described (Kaczmarek et al., 1980). The protein inhibitor of cAMP-dependent protein kinase was purified from rabbit skeletal muscle, essentially as described by McPherson et al. (1979). cGMP-dependent protein kinase purified from bovine lung (Walter et al., 1980) was a gift from Dr. Robert Lewis of this laboratory.

\section{Sample preparation}

Male Sprague-Dawley rats (150-200 gm body weight) were stunned and decapitated. The brains plus various peripheral organs were rapidly placed in ice-cold $0.32 \mathrm{M}$ sucrose ( $\mathrm{pH} 7.4)$. The cerebellum and, in some experiments, the cerebral cortex, the neostriatum (caudatoputamen), and several other brain regions were carefully dissected as previously dcscribed (Walaas et al., 1983a).

Mice were obtained from Jackson Laboratories (Bar Harbor, ME). The mutants used were Weaver (strain B6CBA ${ }^{\text {w-j } / A}$ ), Nervous (strain $\mathrm{C} 3 \mathrm{HeB} / \mathrm{FeJ}$ ), and Purkinje cell degeneration (PCD; strain C57BL/6J). The homozygous mutants were identified by their abnormal gait and smaller size as compared with their littermates. The animals used as controls in the present study were littermates, consisting of two-thirds heterozygotes and one-third homozygous wild type. These could not be distinguished by any behavioral means and are collectively termed $+/$ ? Both males and females were used. The mice were killed at 3.5-4 months of age by cervical dislocation. Their brains were rapidly placed in icecold $0.32 \mathrm{~m}$ sucrose (pH 7.4), and the cerebellum, neostriatum, and cerebral cortex were dissected. The rat and mouse samples were rapidly frozen and either analyzed immediately or stored at $-70^{\circ} \mathrm{C}$.

Samples from human and monkey cerebellum were obtained from Dr. T. Bartfai (University of Stockholm, Sweden). The human sample was taken from the cerebellar hemisphere of an 84-year-old, neurologically normal female whose brain had been frozen within $3 \mathrm{hr}$ postmortem and maintained at $-70^{\circ} \mathrm{C}$ until analysis. Monkey cerebella (Macaca mulatta) were derived from 5-10-year-old healthy animals. The brains were removed within 2 min postmortem, rapidly frozen, and kept at $-70^{\circ} \mathrm{C}$ until analysis. Bovine cerebella, obtained from a local slaughterhouse, were kept on ice during transport to the laboratory and then frozen at $-70^{\circ} \mathrm{C}$ until analysis.

Weighed tissue samples were thawed and homogenized, with 20 strokes in a glass-Teflon homogenizer rotating at $2100 \mathrm{rpm}$, in $10 \mathrm{vol}$ ice-cold standard buffer containing $10 \mathrm{~mm}$ Tris- $\mathrm{HCl}(\mathrm{pH} 7.4), 1 \mathrm{~mm}$ dithiothreitol, $1 \mathrm{~mm}$ EDTA, and 50 units $/ \mathrm{ml}$ of the protease inhibitor, Trasylol, and $\mathrm{kcpt}$ on ice while protein concentration was determined with a dyebinding assay (Bradford, 1976). The homogenates were in some cases further separated into total particulate and soluble preparations by centrifugation at $150,000 \times g$ for $30 \mathrm{~min}$ at $4^{\circ} \mathrm{C}$, as previously described (Walaas et al., 1983a, b). 


\section{Subcellular fractionation}

Subcellular fractions from rat cerebellum were prepared by differential centrifugation at $4^{\circ} \mathrm{C}$ (Whittaker and Barker, 1972). Rat cerebella were homogenized, with 10 strokes in a glass-Teflon homogenizer rotating at $900 \mathrm{rpm}$, in $10 \mathrm{vol}$ of ice-cold $0.32 \mathrm{M}$ sucrose in standard buffer. The homogenate was centrifuged at $900 \times g$ for $10 \mathrm{~min}$, and the pellet was washed once in the original volume of sucrose/standard buffer to yield a nuclear fraction $\left(\mathrm{P}_{1}\right)$. The pooled supernatants were centrifuged at $12,000 \times g$ for 20 min to yield a crude synaptosomal fraction $\left(\mathrm{P}_{2}\right)$ and a supernatant, which was then centrifuged at $150,000 \times g$ for $30 \mathrm{~min}$ to yield a crude microsomal fraction $\left(\mathrm{P}_{3}\right)$ and a final cytosol fraction (S). All particulate fractions were resuspended by means of glass-Teflon homogenizers in the original volume of standard buffer. Triton X-100 (final concentration, $0.2 \% \mathrm{vol} / \mathrm{vol}$ ) was then added to all subcellular fractions to insure solubilization of tissue components. The fractions were kept on ice until protein content and phosphoproteins were analyzed.

\section{Extraction of cerebellar proteins}

To study the ability of salt and of detergent to extract cerebellar proteins, microsomal fractions $\left(\mathrm{P}_{3}\right)$ or, in some experiments, total particulate fractions were resuspended in ice-cold standard buffer containing either $\mathrm{KCl}$ or $\mathrm{NaCl}(0.15$ or $0.5 \mathrm{M})$, or Triton $\mathrm{X}-100(0.5 \%$, vol/vol). The samples were mixed vigorously and kept on ice for $60 \mathrm{~min}$, whereupon $0.5 \mathrm{ml}$ aliquots were centrifuged at $150,000 \times g$ for $30 \mathrm{~min}$. The supernatants, which contained the extracted proteins, were collected, and the pellets were resuspended in standard buffer with glass-Teflon homogenizers. The extracts were dialyzed overnight against standard buffer before analysis.

\section{Phosphorylation of proteins in tissue samples}

Phosphorylation was carried out as described previously (Walaas et al., 1983a). Aliquots containing 50-150 $\mu \mathrm{g}$ protein were incubated in a standard medium (final volume, $0.1 \mathrm{ml}$ ) containing (final concentration) $25 \mathrm{~mm}$ Tris- $\mathrm{HCl}$ (pH 7.4), $6 \mathrm{~mm} \mathrm{MgSO}_{4}, 1$ mм EDTA, 1 mм EGTA, $1 \mathrm{~mm}$ dithiothreitol, and $2 \mu \mathrm{M} \gamma{ }^{-32} \mathrm{P}-\mathrm{ATP}(10-30 \mathrm{Ci} / \mathrm{mmol})$ and other additions as indicated. The samples were preincubated for $60 \mathrm{sec}$ at $30^{\circ} \mathrm{C}$. The reaction was initiated by addition of $\gamma-{ }^{32} \mathrm{P}-\mathrm{ATP}$ and terminated after $60 \mathrm{sec}$ by addition of a SDS-containing "stop solution" (Ueda and Greengard, 1977); this was followed by boiling for $2 \mathrm{~min}$. The phosphoproteins were then either separated by one-dimensional SDSPAGE (Laemmli and Favre, 1973) or by the detergent-urea, two-dimensional gel electrophoretic system developed for cell surface proteins by Imada and Sueoka (1980). The gels were fixed, stained, destained, and dried, and phosphoproteins were visualized by autoradiography (Ueda and Greengard, 1977). The apparent molecular weights of protein bands were determined by comparison with standard proteins, as described by Walaas et al. (1983a). For quantitation, specific phosphoprotein bands were cut out of the gels by using the autoradiograms as guides, and ${ }^{32} \mathrm{P}$ content was measured by liquid scintillation spectrometry. In some experiments, the gel pieces were further processed for peptide mapping, using either $S$. aureus V8 protease or trypsin as described by Cleveland et al. (1977) and Huttner and Greengard (1979).

\section{Phosphorylation of proteins in acid extracts}

The experimental procedures described above were found satisfactory for the qualitative demonstration of the presence or absence of PCPP260 . However, such procedures were not well suited for precise quantitation of protein phosphorylation, as has been discussed in detail elsewhere (Walaas et al., 1983a). Acid/detergent extraction, which inactivates endogenous protein kinases and phosphatases (Forn and Greengard, 1978) and is therefore suitable for precise quantitative determination of acid-soluble phosphoproteins, was used for such quantitation. In preliminary experiments with membranes that had been phosphorylated with $\gamma^{-32} \mathrm{P}$-ATP and the catalytic subunit of cAMPdependent protein kinase, this extraction technique was found to accomplish reproducible solubilization of $50-60 \%$ of the ${ }^{32} \mathrm{P}$-labeled PCPP-260 when Triton X-100 was included during the extraction procedure (not shown).

In brief, tissue was homogenized in standard buffer and total homogenates were incubated at $30^{\circ} \mathrm{C}$ for $20 \mathrm{~min}$. This treatment is known to dephosphorylate endogenous phosphoproteins (Forn and Greengard, 1978; Rauch and Roskoski, 1984; Walaas and Greengard, 1984). Zinc

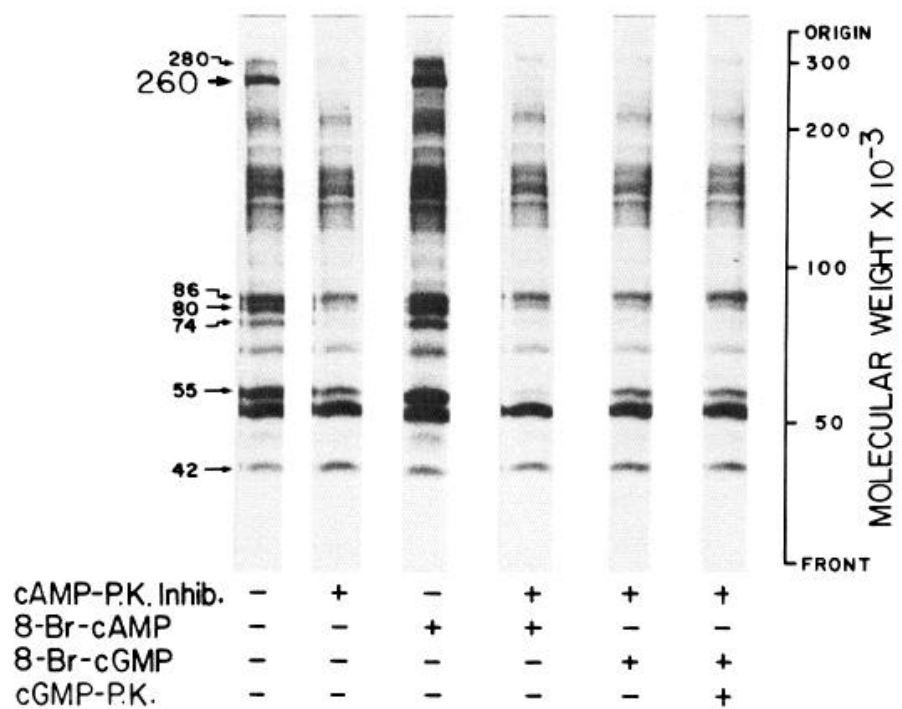

Figure 1. Autoradiogram showing phosphorylation of PCPP-260 by cAMP-dependent protein kinase. Aliquots containing equal amounts of total particular protein, prepared from rat cerebellum, were incubated with $\mathrm{Mg} \gamma{ }^{-32} \mathrm{P}$-ATP in the absence or presence of the heat-stable protein inhibitor of cAMP-dependent protein kinase (P.K. Inhib., $18 \mu \mathrm{g} / \mathrm{ml})$, 8-bromo-cAMP (8-Br-cAMP, $2 \mu \mathrm{M}), 8$-bromo-cGMP (8-Br-cGMP, 2 $\mu \mathrm{M})$, or the purified cGMP-dependent protein kinase (cGMP-P.K., 10 $\mathrm{nM}$ ), as indicated. After incubation at $30^{\circ} \mathrm{C}$ for $60 \mathrm{sec}$, the reactions were terminated by addition of SDS-containing stop solution and boiling, and the phosphoproteins were separated by SDS-PAGE on an $8 \%$ polyacrylamide gel and visualized by autoradiography. The arrows indicate the following proteins: 280 , MAP-2; 260 , cerebellum-specific 260,000 Da phosphoprotein (PCPP-260); 86, synapsin Ia; 80, synapsin Ib; 74, Protein IIIa; 55, Protein IIIb; 42, $\alpha$-subunit of pyruvate dehydrogenase.

acetate, $5 \mathrm{~mm}$, was added, and precipitated proteins were collected by centrifugation and extracted with $10 \mathrm{~mm}$ citrate-phosphate buffer $\mathrm{pH}$ 2.8) containing $0.2 \%$ Triton X-100 and $2 \mu \mathrm{g} / \mathrm{ml}$ Pepstatin A as previously described (Walaas and Greengard, 1984). Protein content was determined in the final extracts (Bradford, 1976), which were then adjusted to equal protein concentration. The phosphoproteins present in equal aliquots of the neutralized acid extracts were quantitated by "backphosphorylation" in a medium (final volume, $0.1 \mathrm{ml}$ ) containing (final concentration) $50 \mathrm{~mm}$ HEPES ( $\mathrm{pH} 7.4$ ), $10 \mathrm{~mm} \mathrm{MgCl}_{2}, 1 \mathrm{~mm}$ EDTA, $1 \mathrm{~mm}$ EGTA, $25 \mathrm{~nm}$ catalytic subunit of cAMP-dependent protein kinase, and $10 \mu \mathrm{M} \gamma{ }^{-32} \mathrm{P}$-ATP $(10-30 \mathrm{Ci} / \mathrm{mmol})$. The samples were incubated at $30^{\circ} \mathrm{C}$ for $30 \mathrm{~min}$, and the phosphorylation reaction terminated by addition of SDS-stop solution. The phosphoproteins were then separated by one-dimensional or two-dimensional gel electrophoresis and visualized by autoradiography of the dried gels. ${ }^{32} \mathrm{P}$ incorporation into specific protein bands was quantitated as described above. These incubation conditions were found to give maximal incorporation of ${ }^{32} \mathrm{P}$ into PCPP-260, as well as into synapsin Ia and Ib and Proteins IIIa and IIIb, nervous tissue-specific phosphoproteins which are known to be extracted with high efficiency by the acid-extraction technique (Huang et al., 1982; Ueda and Greengard, 1977). The incorporation of ${ }^{32} \mathrm{P}$ into these proteins, therefore, gives a quantitative measure of the proteins present in the extracts. However, the extent of phosphorylation of PCPP260 in these extracts is not known, and the true amount of PCPP-260 in the tissues can therefore as yet not be determined with this technique. Nevertheless, the method can be used to compare PCPP-260 within individual experiments.

\section{Results}

cAMP-dependent phosphorylation of PCPP-260

In our original study reporting the existence of the $260 \mathrm{kDa}$ phosphoprotein (PCPP-260) in rat cerebellum, we observed 


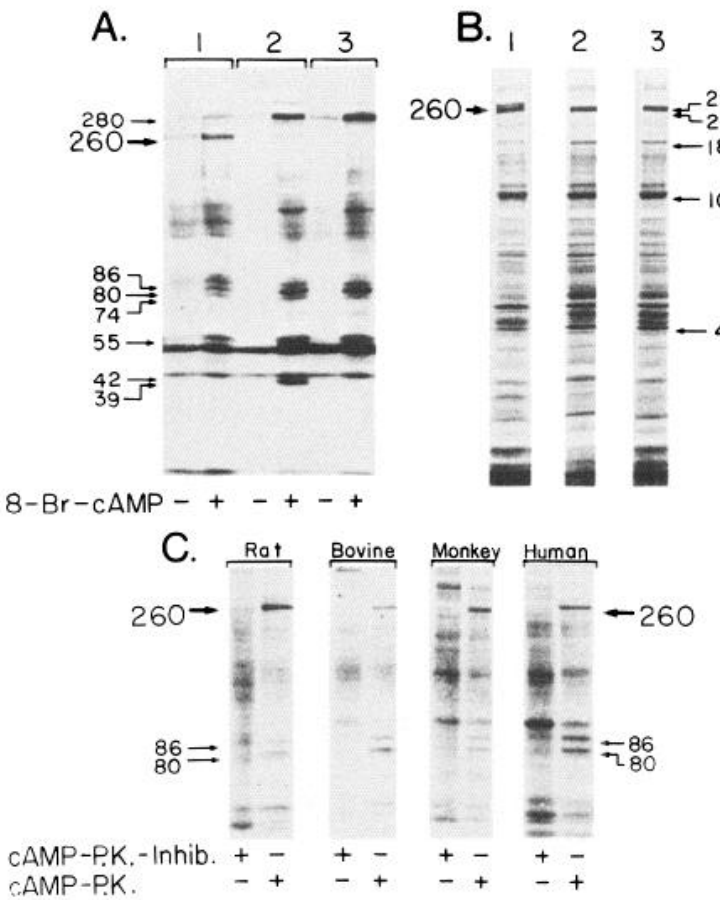

Figure 2. Distribution of PCPP-260 in mammalian brain. Total particulate fractions were prepared from rat cerebellum (1), neostriatum (2), and cerebral cortex (3), as described in the text. A, Aliquots containing equal amounts of protein were phosphorylated in the absence or presence of 8-bromo-cAMP (8-Br-cAMP, $2 \mu \mathrm{M}$ ), as described in the legend to Figure 1, and the phosphoproteins were separated by SDSPAGE on a linear 6-12\% gradient polyacrylamide gel and visualized by autoradiography. The arrows indicate as follows: 39 , striatum-specific 39,000 Da phosphoprotein; others as in Figure 1. B. The proteins were separated on an $8 \%$ polyacrylamide gel for visualization by Coomassie blue. Numbers indicate molecular weight of major protein bands. $C$, Total particulate fractions from the cerebella of various mammalian species were phosphorylated as described above, with the addition of $0.2 \%$ Triton X-100 to the medium, in the absence or presence of the protein kinase inhibitor $(18 \mu \mathrm{g} / \mathrm{ml})$ or the catalytic subunit of cAMPdependent protein kinase $(20 \mathrm{nM})$, as indicated. The reactions were terminated and the phosphoproteins were separated and visualized as described above. Only the high-molecular-weight regions of the gels are shown. Phosphoproteins are indicated as above.

phosphorylation of this protein in the absence and, to a greater extent, in the presence of added cAMP (Walaas et al., 1983a). The protein kinase responsible for phosphorylation in the absence of added cyclic nucleotide was not identified. In the present study, total particulate preparations from rat cerebelllum were used to characterize the protein kinase that catalyzes the phosphorylation of PCPP-260. Incubation of these preparations with $\gamma{ }^{32} \mathrm{P}$-ATP and $\mathrm{Mg}^{2+}$ in the presence of 8-bromo-cAMP (Fig. 1) or the purified catalytic subunit of cAMP-dependent protein kinase (not shown) stimulated ${ }^{32} \mathrm{P}$ incorporation into PCPP-260 greater than that observed under basal conditions, whereas incubation with the purified heat-stable protein inhibitor of cAMP-dependent protein kinase led to an almost complete inhibition of ${ }^{32} \mathrm{P}$ incorporation into PCPP-260 (Fig. 1). Furthermore, the phosphorylation of microtubule-associated protein 2 (MAP-2) (280 kDa), as well as the synaptic vesicleassociated proteins, synapsin $\mathrm{Ia}$ and $\mathrm{Ib}(86 \mathrm{kDa}$ and $80 \mathrm{kDa})$ and Proteins IIIa and IIIb (74 kDa and $55 \mathrm{kDa}$ ), all of which are well-known substrates for cAMP-dependent protein kinase (Browning et al., 1982; Huang et al., 1982; Ueda and Greengard, 1977; Walaas et al., 1983a), was regulated by these additions in a similar way (Fig. 1). These results indicate that PCPP-260 can be phosphorylated in particulate preparations by both intrinsic
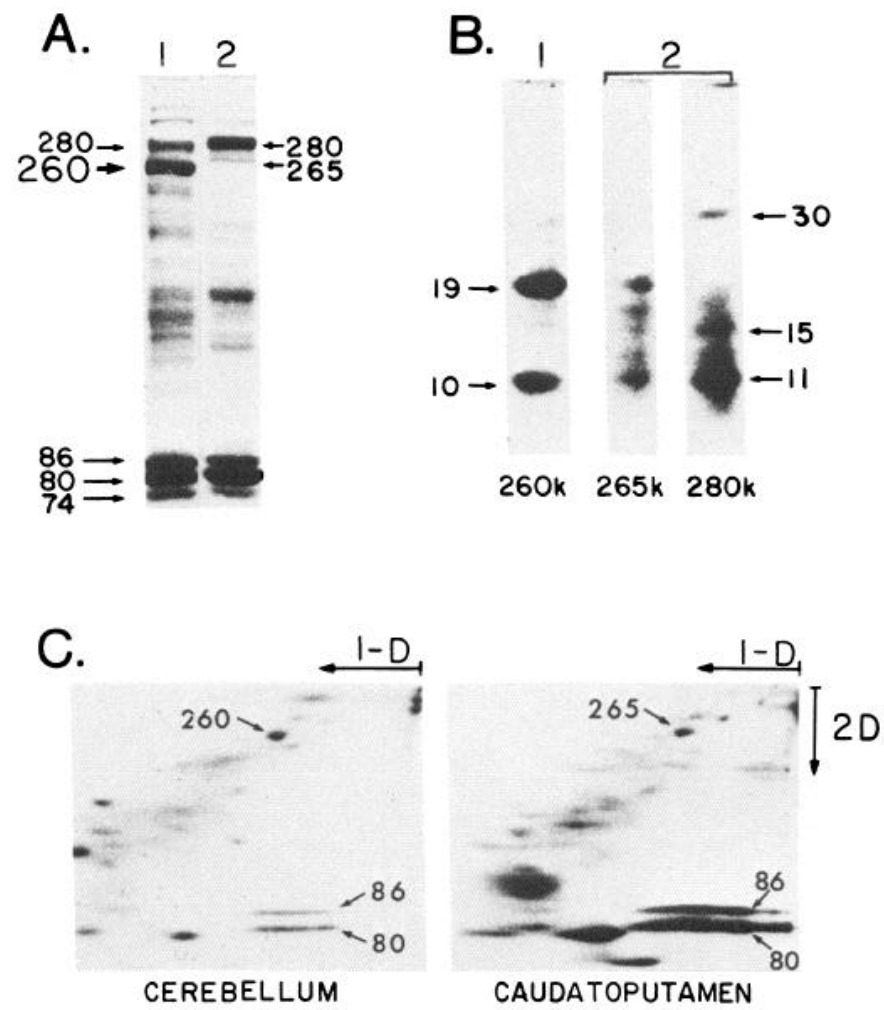

Figure 3. Demonstration of similarities between PCPP-260 and a 265 $\mathrm{kDa}$ forebrain protein. $A$, Total particulate preparations from neocortex (1) and cerebellum (2) were phosphorylated in the presence of 8-bromocAMP, as described in the legend to Figure 1, and the phosphoproteins were separated by SDS-PAGE on $6 \%$ acrylamide gels and visualized by autoradiography. A distinct difference in mobility between PCPP-260 (260) and the $265 \mathrm{kDa}$ protein (265) can be observed, whereas both MAP-2 (280) and synapsin Ia and Ib (86 and 80) display identical mobilities in the two preparations. $B$, Peptide maps of the high-molecular-weight phosphoproteins shown in $A$ demonstrating relationship between PCPP- 260 and the $265 \mathrm{kDa}$ protein. The indicated bands $(260 \mathrm{k}$, $265 \mathrm{k}, 280 \mathrm{k}$ ) were cut out of the gel with the autoradiogram as guide and subjected to incomplete proteolysis with $1 \mu \mathrm{g}$ of $S$. aureus V8 protease; the phosphopeptides were separated on $15 \%$ acrylamide gels and visualized as described in the text. Numbers indicate apparent molecular weight of the major phosphopeptide fragments generated from PCPP-260, the $265 \mathrm{kDa}$ protein, or MAP-2 $(280 \mathrm{k})$. $C$, Two-dimensional electrophoresis of brain phosphoproteins, demonstrating similar mobilities of PCPP- 260 and the $265 \mathrm{kDa}$ protein. Total homogenates from rat cerebellum and caudatoputamen were phosphorylated in the presence of 8-bromo-cAMP, as described in the legend to Figure 1. Aliquots containing $250 \mu \mathrm{g}$ protein from the caudatoputamen or $50 \mu \mathrm{g}$ protein from the cerebellum were separated by two-dimensional electrophoresis, and the phosphoproteins were visualized by autoradiography. $1-D$, first dimension performed on urea-SDS-Triton CF-10 gels; $2 D$, second dimension performed on 7-15\% gradient SDS-PAGE. Arrows indicate as follows: 260 , PCPP-260; 265, $265 \mathrm{kDa}$ forebrain protein; 86 and 80 , synapsin Ia and Ib. Only the parts of the gels containing high-molecularweight proteins are shown in $A$ and $C$.

and exogenous cAMP-dependent protein kinase. The effect of the protein kinase inhibitor also suggests that the particulate preparation from rat cerebellum contains a partially activated endogenous cAMP-dependent protein kinase. The high postmortem levels of cyclic nucleotides known to occur in the rodent cerebellum may have been responsible for this activation (Corda et al., 1980; Ferrendelli et al., 1973).

cGMP-dependent protein kinase, calcium/calmodulin-dependent protein kinase, and calcium/phospholipid-dependent protein kinase are also present in the cerebellum (Bandle and Guidotti, 1978; Greengard and Kuo, 1970; Lohmann et al., 


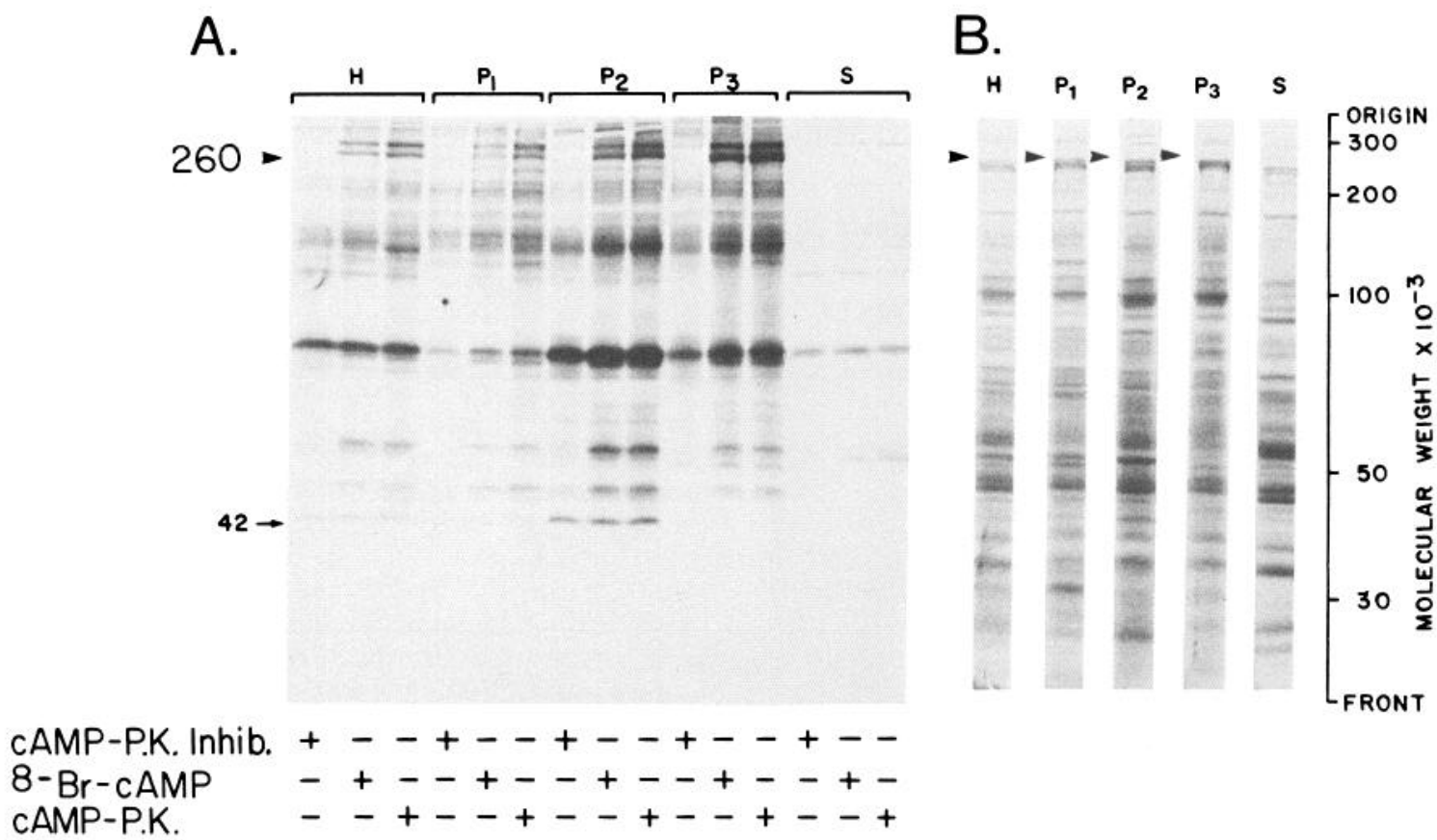

Figure 4. Distribution of PCPP-260 in various subcellular fractions from rat cerebellum. Cerebellar homogenates $(H)$, and nuclear $\left(P_{1}\right)$, crude synaptosomal $\left(P_{2}\right)$, microsomal $\left(P_{3}\right)$ and soluble fractions $(S)$ were prepared and treated with Triton X-100, as described in the text. Aliquots containing equal amounts of protein were phosphorylated (as described in the legend to Fig. 1$)$ in the presence of the protein kinase inhibitor $(P . K$. Inhib., $18 \mu \mathrm{g} / \mathrm{ml}), 8$-bromo-cAMP $(8-B r-c A M P, 2 \mu \mathrm{M})$, or the catalytic subunit of cAMP-dependent protein kinase (cAMP-P.K., $20 \mathrm{nM})$ as indicated. The phosphoproteins were then separated by SDS-PAGE on $8 \%$ acrylamide gels and visualized by autoradiography. $A$, Autoradiogram of phosphoproteins. $B$, Coomassie blue-stained protein bands. Arrowheads, PCPP-260, which is seen to be restricted to particulate fractions. 42, $\alpha$-Subunit of pyruvate dehydrogenase.

1981; Walaas et al., 1983a, b). Therefore, we investigated whether PCPP-260 could be phosphorylated by any of these protein kinases. Addition of 8-bromo-cGMP to cerebellar homogenates (not shown) and addition of 8-bromo-cGMP with or without exogenous cGMP-dependent protein kinase to particulate preparations (Fig. 1) did not lead to phosphorylation of the protein. Furthermore, activation of endogenous calcium/calmodulin-dependent or calcium/phospholipid-dependent protein kinase in cerebellar homogenates did not reproducibly stimulate the phosphorylation of any $260 \mathrm{kDa}$ protein (not shown). These studies, then, suggest that PCPP-260 may be a specific substrate for cAMP-dependent protein kinase.

\section{Distribution of PCPP-260}

Since PCPP-260 is a substrate for cAMP-dependent protein kinase, phosphorylation of total particulate preparations from various parts of the rat brain in the absence or presence of 8-bromo-cAMP was used to study the distribution of the protein. Figure 2 shows that PCPP-260 is highly enriched in the cerebellum. Phosphorylation of samples from striatum, cerebral cortex (Fig. 2), or several other brain regions (Walaas et al., 1983a) failed to show the protein in other parts of the brain. A similar distribution of PCPP-260 was observed when samples were phosphorylated in the presence of added catalytic subunit of cAMP-dependent protein kinase (not shown). PCPP-260 was also seen when total particulate preparations from bovine, monkey, human (Fig. 2), or mouse cerebella were analyzed, but it was not detected when several non-nervous tissues were examined with this technique (not shown).

Comparison of the autoradiogram with the Coomassie bluestained gels showed that PCPP-260 comigrated with a major cerebellum-enriched, protein-staining band on both one-dimensional (Fig. 2) and two-dimensional electrophoresis (not shown); evidence presented throughout this paper suggests that these two bands represent the same entity. Both the stained protein band and the phosphoprotein migrated on SDS-PAGE close to a $235-250 \mathrm{kDa}$ doublet (Fig. 2), which probably represents the recently purified and characterized spectrin-like protein that has been designated fodrin (Levine and Willard, 1981) or calspectin (Kakiuchi et al., 1982).

Our experiments also showed the presence of other, more widely distributed particulate brain phosphoproteins, the distributions of which can be contrasted to that of PCPP-260. These include MAP-2, synapsin Ia and Ib, Proteins IIIa and IIIb, and the mitochondrial $\alpha$-subunit of pyruvate dehydrogenase (42 $\mathrm{kDa}$-all of which are present throughout the CNS-and a distinct $39 \mathrm{kDa}$ phosphoprotein enriched only in the neostriatum (Walaas et al., 1983a) (Fig. 2).

Close inspection of the autoradiograms also revealed a minor particulate phosphoprotein, which had an apparent $M_{r}$ close to that of PCPP-260. This protein was seen in many forebrain regions, for example, the neocortex, caudatoputamen (Fig. 2), hippocampus, nucleus accumbens, olfactory tubercle, globus pallidus, and amygdala, but not in brain stem regions such as diencephalon, mesencephalon, pons/medulla, or the spinal cord (not shown). Samples from the neocortex, caudatoputamen, and cerebellum were used to study the relationship of this protein to PCPP-260 in more detail. Using gels with low acrylamide concentration, we found that this phosphoprotein consistently showed a lower electrophoretic mobility than PCPP-260 upon SDS-PAGE and that it had an apparent $M_{r}$ of 265,000 (Fig. 3). However, peptide mapping of PCPP-260 and the $265 \mathrm{kDa}$ phosphoprotein, using incomplete digestion with $S$. aureus V8 protease followed by SDS-PAGE, showed that the two proteins generated very similar phosphopeptides, with major phosphopeptide fragments of $10 \mathrm{kDa}$ and $19 \mathrm{kDa}$ being found in both samples. MAP-2, in contrast, gave major phosphopeptides of 30,15 , and $11 \mathrm{kDa}$ (Fig. 3). Several minor phosphoproteins seen in the digest from the $265 \mathrm{kDa}$ protein suggested that this protein might contain other components. However, separation 


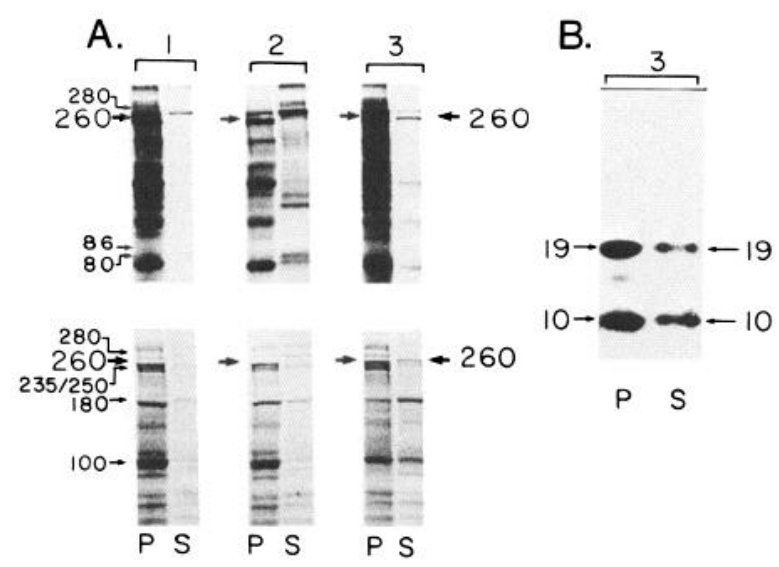

Figure 5. Extraction of PCPP-260 from microsomal fraction of rat cerebellum. $A$, Aliquots of the microsomal fraction $\left(\mathrm{P}_{3}\right)$ were resuspended in standard buffer containing no additions (1), $0.5 \mathrm{M} \mathrm{NaCl}(2)$, or Triton X-100 $(0.5 \%, \mathrm{vol} / \mathrm{vol})(3)$ and incubated for $60 \mathrm{~min}$ at $4^{\circ} \mathrm{C}$. Solubilized proteins were removed by centrifugation and dialyzed overnight, while the pellets were resuspended in the original volume of standard buffer. Aliquots from supernatants and pellets representing equal amounts of starting material were then phosphorylated as described in the legend to Figure 1 in the presence of catalytic subunit of cAMP-dependent protein kinase (cAMP-P.K., $25 \mathrm{nM}$ ), and the phosphoproteins were separated by SDS-PAGE on $8 \%$ acrylamide gels and visualized by autoradiography. Upper lane, Autoradiogram of phosphoproteins. Lower lane, Coomassie blue-stained protein bands. Only high-molecular-weight proteins are shown. $B$, Autoradiogram of phosphopeptide fragments generated by limited proteolysis from particulate or solubilized PCPP-260 in the detergent-treated sample (3). Gel pieces containing PCPP-260 were cut out from the gel shown in $A$ and subjected to limited proteolysis with $1 \mu \mathrm{g} \mathrm{S}$. aureus V8 protease, as described in the legend to Figure 3. $P$, Nonextracted proteins; $S$, solubilized proteins. Numbers indicate apparent molecular weights of proteins in kilodaltons.

of proteins by two-dimensional gel electrophoresis showed that the $260 \mathrm{kDa}$ and $265 \mathrm{kDa}$ proteins had identical mobilities in the first-dimension electrophoresis (Fig. 3). In addition, twodimensional tryptic peptide mapping of the two phosphoproteins cut out from these gels revealed identical phosphopeptides (not shown). Similarly, incomplete digestion of the 260 and 265 $\mathrm{kDa}$ phosphoproteins after acid/detergent extraction showed identical peptide maps (Fig. $6 C$; see below). Thus, the $265 \mathrm{kDa}$ forebrain phosphoprotein is closely related to PCPP- 260 .

Subcellular localization of PCPP-260

Phosphorylation by endogenous or exogenous cAMP-dependent protein kinase was used to analyze various subcellular fractions from rat cerebellum for the presence of PCPP-260. Figure 4 shows that PCPP-260, visualized by autoradiography and by Coomassie blue staining, is restricted to the particulate fractions. Indeed, the protein appears to be enriched in the microsomal fraction $\left(\mathrm{P}_{3}\right)$, which contains predominantly plasma membrane fragments and microsomes (Whittaker and Barker, 1972). Similar results were obtained when acid-detergent extracts from these fractions were analyzed (not shown). This distribution can be contrasted with that of the $42 \mathrm{kDa}$ phosphorylated $\alpha$-subunit of the mitochondrial enzyme, pyruvate dehydrogenase (Walaas et al., 1983a). The latter phosphoprotein is enriched in the crude synaptosomal fraction $\left(\mathrm{P}_{2}\right)$, which contains the mitochondria (Whittaker and Barker, 1972), but it is absent from the microsomal fraction (Fig. 4).

These results indicate that PCPP-260 represents a membranebound protein entity. Therefore, we investigated whether the protein behaved as a peripheral or an integral membrane protein. Treatment of microsomal or total particulate preparations with a nonionic detergent, both at neutral and at acid $\mathrm{pH}$, led to a partial solubilization of PCPP-260, as visualized by both autoradiography and protein staining (Fig. 5). In contrast, treatment with high salt concentrations (Fig. 5) or with acid in the absence of detergent did not solubilize the protein. Peptide maps confirmed that the detergent-solubilized phosphoprotein was identical to the particulate phosphoprotein (Fig. 5). Therefore, PCPP-260 behaved like an integral membrane protein. Similar results were obtained with the $265 \mathrm{kDa}$ protein in forebrain samples (not shown). However, certain other proteins present in the particulate fractions, such as MAP-2, were most efficiently extracted by high concentrations of salt, thus behaving like peripheral membrane proteins (Fig. 5).

\section{Cellular localization of PCPP-260 within the cerebellum}

Cerebella from normal mice and from strains of mutant mice deficient either in Purkinje cells or granule cells were analyzed to determine the cellular localization of PCPP-260. Total particulate preparations or acid-detergent extracts were used to compare the phosphoproteins in the cerebellum, caudatoputamen, and neocortex of these mouse mutants, using both oneand two-dimensional gel electrophoresis and peptide mapping to identify the proteins. Figure 6 illustrates that PCPP-260 was present in the cerebella of control mice, but was essentially absent from the cerebella of homozygous PCD mice, which were almost devoid of Purkinje cells (Mullen et al., 1976). Similarly, PCPP-260 was greatly decreased in the cerebella of homozygous Nervous mice, which have lost most, but not all, Purkinje cells (Sidman and Green, 1970). In contrast, there was an increased concentration of PCPP-260 in the cerebella of the homozygous

Table 1. Concentrations of PCPP-260, synapsin I, Protein IIIa, and Protein IIIb in extracts from cerebella of neurologically mutant mice and their littermate controls

Genotype

\begin{tabular}{|c|c|c|c|c|c|c|}
\hline \multirow{3}{*}{$\begin{array}{l}\text { Phospho- } \\
\text { protein }\end{array}$} & \multirow{2}{*}{\multicolumn{4}{|c|}{ Purkinje cell degeneration }} & & \\
\hline & & & & & \multicolumn{2}{|l|}{ Weaver } \\
\hline & $+/ ?(n=10)$ & $-1-(n=8)$ & $+/ ?(n=3)$ & $-1-(n=3)$ & $+/ ?(n=6)$ & $-/-(n=6)$ \\
\hline PCPP-260 & $2.12 \pm 0.36$ & $0.08 \pm 0.04^{*}$ & $3.35 \pm 0.78$ & $0.64 \pm 0.12^{*}$ & $3.46 \pm 0.97$ & $6.30 \pm 1.08^{* *}$ \\
\hline Synapsin I & $19.08 \pm 1.97$ & $12.60 \pm 0.95^{* *}$ & $18.55 \pm 3.10$ & $12.80 \pm 2.35^{* *}$ & $20.29 \pm 1.43$ & $10.15 \pm 4.32^{*}$ \\
\hline Protein IIIa & $2.08 \pm 0.45$ & $1.75 \pm 0.34$ & $1.43 \pm 0.26$ & n.d. & $2.09 \pm 0.38$ & $1.54 \pm 0.21^{* * *}$ \\
\hline Protein IIIb & $4.85 \pm 0.54$ & $3.88 \pm 0.58^{* * *}$ & $2.71 \pm 0.31$ & n.d. & $3.84 \pm 0.59$ & $2.38 \pm 0.62^{* * * *}$ \\
\hline
\end{tabular}

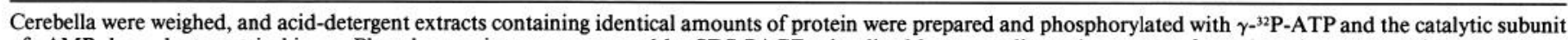

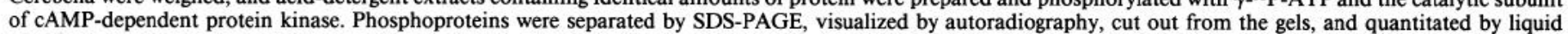

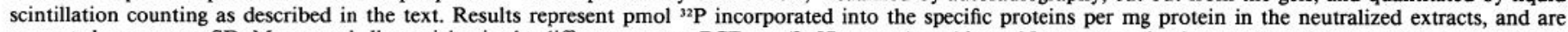

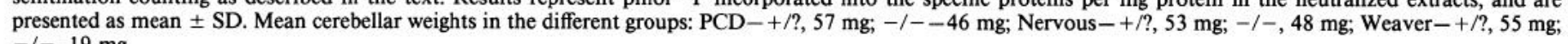
$-/-, 19 \mathrm{mg}$.

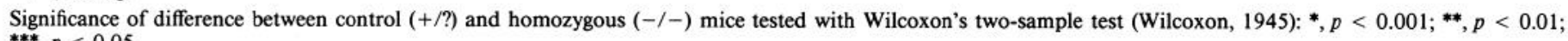
***, $p<0.05$.

n.d. = not determined. 

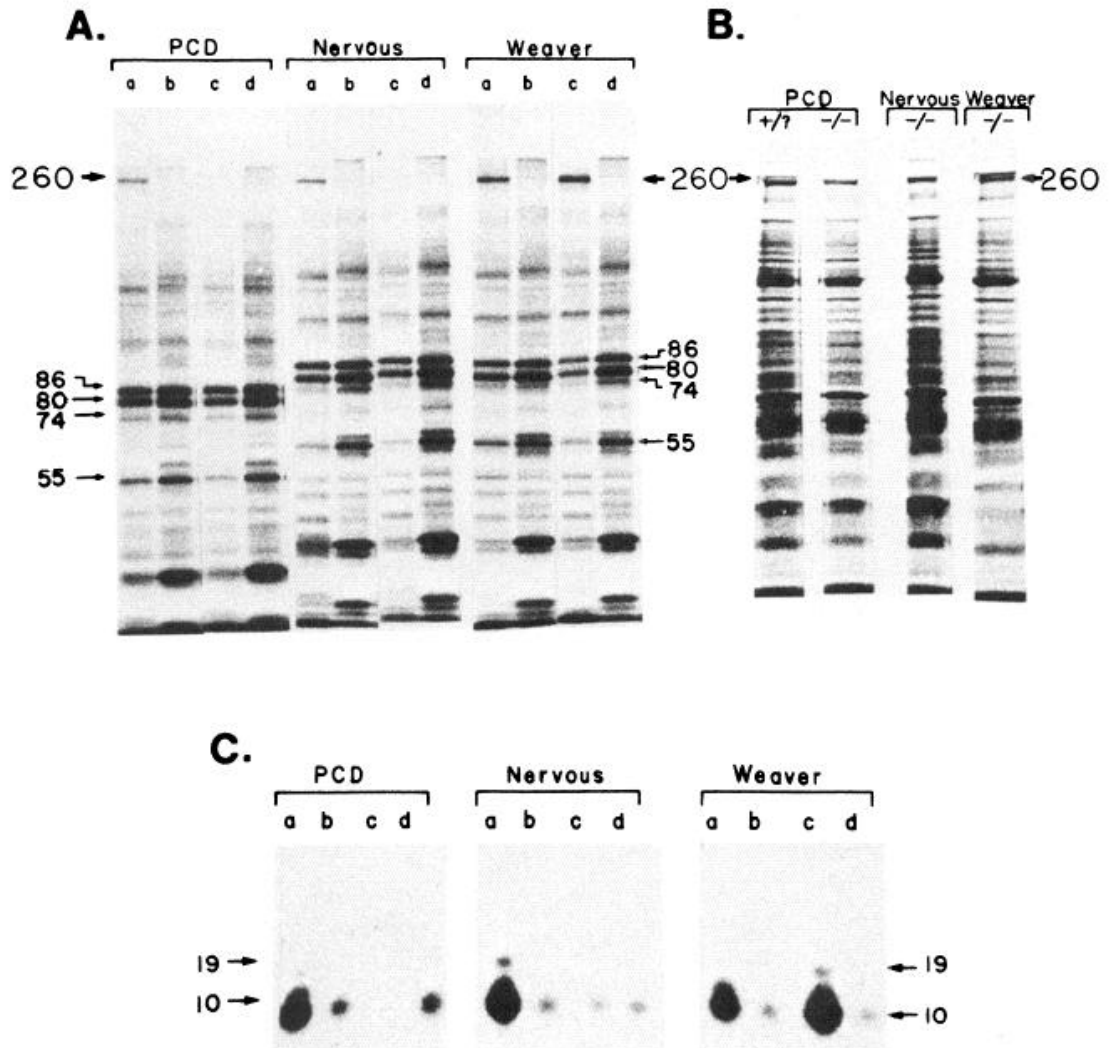

Figure 6. Distribution of PCPP-260 in cerebellum and neostriatum of normal and mutant mice. A, Acid-detergent extracts of total cerebellar ( $a$, $c)$ and neostriatal $(b, d)$ homogenates were prepared from Purkinje cell-deficient (PCD), Nervous, and Weaver mice and their respective control littermates, and phosphorylated in the presence of catalytic subunit of cAMP-dependent protein kinase, as described in the text. After maximal ${ }^{32} \mathrm{P}$ incorporation had been achieved, the phosphoproteins were separated by $6-10 \%$ gradient SDS-PAGE and visualized by autoradiography. $a$, Sample from control cerebellum; $b$, sample from control neostriatum; $c$, sample from mutant cerebellum; $d$, sample from mutant neostriatum. $B$, equal amounts of total particulate proteins from cerebella of $P C D$ control littermate $(+/$ ?), $P C D$ mutant $(-/-)$, Nervous mutant $(-/-)$, and Weaver mutant $(-/-)$ were separated by SDS-PAGE on $8 \%$ acrylamide gels, and the proteins visualized by Coomassie blue staining. PCPP-260 can be seen to be absent or decreased in the PCD and Nervous mutants, but increased in the Weaver mutant. $C$, Gel pieces containing phosphoproteins of $260-265 \mathrm{kDa}$ were cut from the gels shown in $A$, and processed for limited proteolysis with $10 \mu \mathrm{g} S$. aureus V8 protease, as described in the legend to Figure 3. This amount of protease generated predominantly the $10 \mathrm{kDa}$ fragment, which can be seen to be absent from the PCD mutant cerebellum, but present in all other samples.

Weaver mice, which have lost the large population of granule cells and parallel fibers, but have retained the Purkinje cells (Table 1; Rakic and Sidman, 1973).

Calculations of the total amounts of PCPP-260 indicated that the cerebella of homozygous PCD mice contained approximately $3.1 \%$, the cerebella of homozygous Nervous mice $17 \%$, and the cerebella of homozygous Weaver mice $63 \%$ of the total amounts of PCPP-260 found in their respective control littermates (mean values, calculated from Table 1).

In comparison, the concentrations of synapsin I, Protein IIIa, and Protein IIIb, phosphoproteins present in virtually all nerve terminals and therefore useful as general neuronal markers (DeCamilli et al., 1983), were decreased by only $25-35 \%$ in the PCD and Nervous homozygous mutants. The Weaver mutants showed a more pronounced decrease (Table 1), which represented a loss of approximately $80 \%$ of the total amount of these proteins, in agreement with previous reports (e.g., Dolphin and Greengard, 1981). No significant changes were observed in the amounts of synapsin I, Protein IIIa, or Protein IIIb in the caudatoputamen (Fig. 6) or neocortex (not shown) in any of these mutants.

The $265 \mathrm{kDa}$ phosphoprotein was barefly detectable upon SDS-PAGE of phosphorylated acid-detergent extracts from forebrain regions (Fig. 6). However, peptide mapping and twodimensional gel electrophoresis allowed us to analyze this pro- tein in the caudatoputamen and neocortex of the mutant mice. These studies showed that neither the caudatoputamen nor the neocortex had any significant change in the amount or concentration of $265 \mathrm{kDa}$ protein in any of the mutants (Fig. 6; data not shown).

These results, therefore, indicate that, within the cerebellum, PCPP-260 is highly enriched in and may be specific to Purkinje cells. In contrast, many forebrain regions contain small amounts of a closely related $265 \mathrm{kDa}$ phosphoprotein, which appears to be located in cells that are insensitive to the PCD, Nervous, and Weaver mutations.

\section{Discussion}

The $260 \mathrm{kDa}$ phosphoprotein (PCPP-260) analyzed in this paper appears to be specifically concentrated in cerebellar Purkinje cells. The protein has been found in high concentrations in all mammalian cerebella tested so far, and studies on mutant mice indicate a unique enrichment in Purkinje cells. Furthermore, it can be phosphorylated in broken cell preparations by cAMPdependent protein kinase, but apparently not by cGMP-, calcium/calmodulin-, or calcium/phospholipid-dependent protein kinases. This set of properties, together with data indicating that it is an integral membrane protein, suggest that the protein is distinct from certain other high-molecular-weight brain phosphoproteins that have been characterized -for example, the more 
widely distributed protein MAP-2, the microtubule-associated protein, which is a substrate for cAMP-dependent, calcium/ calmodulin-dependent, and calcium/phospholipid-dependent protein kinases (Walaas et al., 1983b). However, PCPP-260 is apparently closely related to a minor $265 \mathrm{kDa}$ phosphoprotein present throughout the telencephalon, since the two proteins share subcellular localization, extractability, protein kinase specificity, electrophoretic mobility upon mixed detergent-urea gel electrophoresis, and one- and two-dimensional phosphopeptide maps, but exhibit slight differences in mobility upon SDS-PAGE. An understanding of the exact relationship between these two proteins requires further study.

Protein staining of the cerebellar proteins after one- or twodimensional electrophoresis suggests that PCPP-260 may constitute a major component of the Purkinje cells, since the phosphoprotein has the same molecular mass and electrophoretic mobility as a distinct Coomassie blue-stained band. This stained protein band is probably identical to the phosphoprotein, since they share brain distributions, are absent from cerebella deficient in Purkinje cells, are enriched in cerebella deficient in granule cells, and have similar subcellular localization and extraction properties.

Previous studies have indicated the existence of a cerebellumspecific glycoprotein with an apparent $M_{r}$ of 400,000 , which was designated $P_{400}$ (Mallet et al., 1976). This protein appears to have a localization similar to that of PCPP-260, since it was found to be restricted to particulate fractions from Purkinje cells (Mallet et al., 1976). Subsequent immunocytochemical studies suggested that $\mathrm{P}_{400}$ was present on Purkinje cell dendrites and cell bodies (Mikoshiba et al., 1979). Other investigators have reported the presence of a membrane glycoprotein with apparent $M$, of 240,000 , which was stated to be restricted to the cerebellum, enriched in synaptic junctions, and partly solubilized by nonionic detergents in the absence of calcium (Groswald and Kelly, 1984; Groswald et al., 1983). A similar glycoprotein of $M_{r} 250,000$ was also found in low concentrations in the forebrain (Aono et al., 1983). The similarities in regional, cellular, and subcellular distribution between the glycoproteins $\left(\mathrm{P}_{400}\right.$ and the 240-250 kDa proteins) and PCPP-260 suggest that the proteins may be identical, with differences in the molccular wcight estimates being the result of the different SDS-PAGE systems used. However, $P_{400}$ has been stated to be insoluble in high concentrations of detergents such as Triton X-100 and deoxycholate (Mikoshiba et al., 1979), in contrast to PCPP-260, which is partly soluble in nonionic detergents. Therefore, the exact relationship between PCPP-260 and the previously described glycoproteins remains to be established.

The well-defined and relatively simple architecture of the mammalian cerebellum (Eccles et al., 1967; Llinas, 1975; Palay and Chan-Palay, 1974) has made this region of the brain particularly attractive for neurochemical and physiological studies. Such studies have revealed that the cAMP-regulated and cGMPregulated protein phosphorylation systems in the cerebellum are differently distributed. cGMP-dependent protein kinase and its substrate (G-substrate) are restricted to the cytosol of Purkinje cells, suggesting a unique functional role for cGMP in this neuron, whereas the cAMP-regulated system is more widely distributed in many cell types, indicating a more widespread role for this second messenger in the cerebellum (Bandle and Guidotti, 1978; Detre et al., 1984; Dolphin et al., 1983; Lohmann et al., 1981; Schlichter et al., 1980). The results described in this paper suggest that the cAMP-regulated phosphorylation of PCPP-260, a Purkinje cell-enriched phosphoprotein, may also play a unique and important functional role in the cerebellar Purkinje cell.

\section{References}

Aono, S., H. Sato, R. Semba, and S. Kashiwamata (1983) Two proteins associated with cerebellar hypoplasia in jaundiced Gunn rats. Neurochem. Res. 8: 743-756.

Bandle, E., and A. Guidotti (1978) Studies on the cell location of cyclic $3^{\prime}, 5^{\prime}$-guanosine monophosphate-dependent protein kinase in cerebellum. Brain Res. 156: 412-416.

Bloom, F. E. (1975) The role of cyclic nucleotides in central synaptic function. Rev. Physiol. Biochem. Pharmacol. 74: 1-103.

Bradford, M. M. (1976) A rapid and sensitive method for the quantitation of microgram quantities of protein utilizing the principle of protein-dye binding. Anal. Biochem. 72: 248-254.

Browning, M. D., C.-K. Huang, and P. Greengard (1982) Biological similarity of two phosphoproteins (Proteins IIIa and IIIb) associated with synaptic vesicles in rat brain. Soc. Neurosci. Abstr. 8: 794.

Cleveland, D. W., S. G. Fischer, M. W. Kirschner, and U. K. Laemmli (1977) Peptide mapping by limited proteolysis in sodium dodecyl sulfate. J. Biol. Chem. 252: 1102-1106.

Corda, M. G., G. Biggio, and G. L. Gessa (1980) Brain nucleotides in naive and handling-habituated rats: Differences in levels and drug sensitivity. Brain Res. 188: 287-290.

DeCamilli, P., R. Cameron, and P. Greengard (1983) Synapsin I (Protein I), a nerve terminal-specific phosphoprotein. I. Its general distribution in synapses of the central and peripheral nervous system demonstrated by immunofluorescence in frozen and plastic sections. J. Cell Biol. 96: 1337-1354.

Detre, J. A., A. C. Nairn, D. W. Aswad, and P. Greengard (1984) Localization in mammalian brain of G-substrate, a specific substrate for guanosine $3^{\prime}: 5^{\prime}$-cyclic monophosphate-dependent protein kinase. J. Neurosci. 4: 2843-2849.

Dolphin, A. C., and P. Greengard (1981) Presence of Protein I, a phosphoprotein associatcd with synaptic vesicles, in cercbellar granule cells. J. Neurochem. 36: 1627-1631.

Dolphin, A. C., J. A. Detre, D. J. Schlichter, A. C. Nairn, H. H. Yeh, D. F. Woodward, and P. Greengard (1983) Cyclic nucleotide-dependent protein kinases and some major substrates in the rat cerebellum after neonatal X-irradiation. J. Neurochem. 40: 577-581.

Eccles, J. C., M. Ito, and J. Szentagothai (1967) The Cerebellum as a Neuronal Machine, Springer-Verlag, Berlin, Heidelberg, New York.

Ferrendelli, J. A. (1978) Distribution and regulation of cyclic GMP in the central nervous system. In Advances in Cyclic Nucleotide Research, Vol. 9, W. J. George and L. J. Ignarro, eds., pp. 453-464, Raven, New York.

Ferrendelli, J. A., D. A. Kinscherf, and M. M. Chang (1973) Regulation of levels of guanosine cyclic $3^{\prime}, 5^{\prime}$-monophosphate in the central nervous systcm. Mol. Pharmacol. 9: 445-454.

Forn, J., and P. Greengard (1978) Depolarizing agents and cyclic nucleotides regulate the phosphorylation of specific neuronal proteins in rat cerebral cortex slices. Proc. Natl. Acad. Sci. USA 75: $5195-$ 5199.

Glynn, I. M. and J. B. Chappel (1964) A simple method for the preparation of ${ }^{32} \mathrm{P}-$ labelled adenosine triphosphate of high specific activity. Biochem. J. 90: 147-149.

Grand, R. J. A., S. V. Perry, and R. A. Weeks (1979) Troponin C-like proteins (calmodulins) from mammalian smooth muscle and other tissues. Biochem. J. 177: 521-529.

Greengard, P. (1978) Phosphorylated proteins as physiological effectors. Science 199: 146-152.

Greengard, P. (1981) Intracellular signals in the brain. Harvey Lect. 75: 277-331.

Greengard, P., and J. F. Kuo (1970) On the mechanism of action of cyclic AMP. In Advances in Biochemical Psychopharmacology, Vol. 3, E. Costa and P. Greengard, eds., pp. 287-306, Raven, New York.

Groswald, D. E., and P. T. Kelly (1984) Evidence that a cerebellum enriched, synaptic junction glycoprotein is related to fodrin and resists extraction with Triton in a calcium-dependent manner. J. Neurochem. 42: 534-546.

Groswald, D. E., P. R. Montgomery, and P. T. Kelly (1983) Synaptic junctions isolated from cerebellum and forebrain: Comparisons of morphological and molecular properties. Brain Res. 278: 63-80.

Huang, C.-K., M. D. Browning, and P. Greengard (1982) Purification 
and characterization of Protein IIIb, a mammalian brain phosphoprotein. J. Biol. Chem. 257: 6524-6528.

Huttner, W. B., and P. Greengard (1979) Multiple phosphorylation sites in Protein I and their differential regulation by cyclic AMP and calcium. Proc. Natl. Acad. Sci. USA 76: 5402-5406.

Imada, M., and N. Sucoka (1980) A two-dimensional polyacrylamide gel electrophoresis system for the analysis of mammalian cell surface proteins. Biochim. Biophys. Acta 625: 179-192.

Kaczmarek, L. K., K. R. Jennings, F. Strumwasser, A. C. Nairn, U. Walter, F. D. Wilson, and P. Greengard (1980) Microinjection of catalytic subunit of cyclic AMP-dependent protein kinase enhances calcium action potentials of bag cell neurons in cell culture. Proc. Natl. Acad. Sci. USA 77: 7487-7491.

Kakiuchi, S., K. Sobue, K. Kanda, K. Morimoto, S. Tsukita, H. Ishikawa, and M. Kurokowa (1982) Correlative biochemical and morphological studies of brain calspectin: A spectrin-like calmodulinbinding protein. Biomed. Res. 3: 400-410.

Laemmli, U. K., and M. Favre (1973) Maturation of the head of bacteriophage T4. I. DNA packaging events. J. Mol. Biol. 80: 575599.

Levine, J., and M. Willard (1981) Fodrin: Axonally transported polypeptides associated with the internal periphery of many cell types. $J$. Cell Biol. 90: 631-643.

Llinas, R. R. (1975) The cortex of the cerebellum. Sci. Am. 232: 5671.

Lohmann, S. M., U. Walter, P. E. Miller, P. Greengard, and P. DeCamilli (1981) Immunohistochemical localization of cyclic GMP-dependent protein kinase in mammalian brain. Proc. Natl. Acad. Sci. USA 78: 653-657.

Mallet, J., M. Huchet, R. Pougeouis, and J.-P. Changeux (1976) Anatomical, physiological and biochemical studies on the cerebellum from mutant mice. III. Protein differences associated with the weaver, staggerer and nervous mutations. Brain Res. 103: 291-312.

McPherson, J. M., S. Whitehouse, and D. A. Walsh (1979) Possibility of shape conformers of the protein inhibitor of the cyclic adenosine monophosphate-dependent protein kinase. Biochemistry 18: 48354845 .

Mikoshiba, K., M. Huchet, and J.-P. Changeux (1979) Biochemical and immunological studies on the $\mathrm{P}_{400}$ protein, a protein characteristic of the Purkinje cell from mouse and rat cerebellum. Dev. Neurosci. 2: $254-275$.

Mullen, R. J., E. M. Eicher, and R. L. Sidman (1976) Purkinje cell degeneration, a new neurological mutation in the mouse. Proc. Natl. Acad. Sci. USA 73: 208-212.

Nairn, A. C., and P. Greengard (1983) Cyclic GMP-dependent protein phosphorylation in the mammalian brain. Fed. Proc. 42: 3107-3113.
Palay, S. L., and V. Chan-Palay (1974) Cerebellar Cortex: Cytology and Organization, Springer-Verlag, Berlin, Heidelberg, New York.

Rakic, P., and R. L. Sidman (1973) Sequence of developmental abnormalities leading to granule cell deficit in cerebellar cortex of weaver mutant mice. J. Comp. Neurol. 152: 103-132.

Rauch, N., and R. Roskoski, Jr. (1984) Characterization of cyclic AMP-dependent phosphorylation of neuronal membrane proteins. J. Neurochem. 43: 755-762.

Schlichter, D. J., J. E. Casnellie, and P. Greengard (1978) An endogenous substrate for cGMP-dependent protein kinase in mammalian cerebellum. Nature 273: 61-62.

Schlichter, D. J., J. A. Detre, D. A. Aswad, B. Chehrazi, and P. Greengard (1980) Localization of cyclic GMP-dependent protein kinase and substrate in mammalian cerebellum. Proc. Natl. Acad. Sci. USA 77: 5537-5541.

Sidman, R. L., and M. C. Green (1970) "Nervous," a new mutant mouse with cerebellar disease, in Les Mutants Pathologiques chez l'Animal, M. Sabourdy, ed., pp. 69-79, Edition du C.N.R.S., Paris.

Ueda, T., and P. Greengard (1977) Adenosine 3':5'-monophosphatercgulatcd phosphoprotcin system of neuronal membranes. I. Solubilization, purification and some properties of an endogenous phosphoprotein. J. Biol. Chem. 252: 5155-5163.

Walaas, S. I., and P. Greengard (1984) DARPP-32, a dopamine- and cyclic AMP-regulated phosphoprotein enriched in a dopamine-innervated brain regions. I. Regional and cellular distribution in the rat brain. J. Neurosci. 4: 84-98.

Walaas, S. I., A. C. Nairn, and P. Greengard (1983a) Regional distribution of calcium- and cyclic adenosine $3^{\prime}: 5^{\prime}$-monophosphate-regulated protein phosphorylation systems in mammalian brain. I. Particulate systems. J. Neurosci. 3: 291-301.

Walaas, S. I., A. C. Nairn, and P. Greengard (1983b) Regional distribution of calcium- and cyclic adenosine $3^{\prime}: 5^{\prime}$-monophosphate-regulated protein phosphorylation systems in mammalian brain. II. Soluble systems. J. Neurosci. 3: 302-311.

Walter, U., P. Miller, F. Wilson, D. Menkes, and P. Greengard (1980) Immunological distinction between guanosine $3^{\prime}: 5^{\prime}$-monophosphatedependent and adenosine $3^{\prime}: 5^{\prime}$-monophosphate-dependent protein kinases. J. Biol. Chem. 255: 3757-3762.

Whittaker, V. P., and L. A. Barker (1972) The subcellular fractionation of brain tissue with special reference to the preparation of synaptosomes and their component organelles. In Methods of Neurochemistry, R. Fried, ed., pp. 1-52, Dekker, New York.

Wilcoxon, F. (1945) Individual comparisons by ranking methods. Biometrics 1: 80-83. 